\title{
PHOSPHORITE PROSPECTION USING GROUND GAMMA SPECTROMETRY IN NORTHEAST GOIÁS STATE, BRAZIL
}

\author{
Chris Busnello Fianco ${ }^{1}$, Roberta Mary Vidotti ${ }^{2}$ and Augusto César Bittencourt Pires ${ }^{3}$
}

ABSTRACT. The Bambuí Group, where the study area is located, is a favorable environment for phosphate rock formation, and hence, is an area of economic interest. The use of gamma ray spectrometry aims at selecting targets for ore exploration, since apatite, a phosphate mineral, generally has a high content of uranium. To this end, approximately 10 linear kilometers (527 stations) of ground gamma ray spectrometry data were acquired, along five profiles, pre-selected based on geophysical data, as well as public domain geochemical and geological information. The analysis of uranium, thorium and potassium and their ratios indicates that the enrichment of $\mathrm{U}$ relative to $\mathrm{K}$ is well mapped by the e $\mathrm{U} / \mathrm{eTh}$ and eU/K ratios, as it was confirmed in the field.

Keywords: ground gamma ray prospection, phosphorites targets, Bambuí Group, uranium

RESUMO. 0 Grupo Bambuí, onde se encontra inserida a área de trabalho, possui um ambiente favorável à formação de rochas fostáticas, apresentando-se assim como uma região de interesse econômico. A utilização do método gamaespectrométrico tem como finalidade a seleção de alvos para prospecção do minério, uma vez que a apatita, mineral fosfático, geralmente apresenta um teor elevado de U. Para este fim foi realizada a aquisição de, aproximadamente, $10 \mathrm{~km}$ lineares, totalizando 527 estações de dados gamaespectrométricos terrestres ao longo de cinco perfis pré-selecionados com base em dados aerogeofísicos, informações geoquímicas e de geologia de domínio público. A análise dos dados dos radioelementos obtidos e de suas razões indica que o enriquecimento de $\mathrm{U}$ em relação ao $\mathrm{K}$, é bem mapeado pelas razões eU/eTh e eU/K, o que foi confirmado em campo.

Palavras-chave: prospecção gamaespectrometria terrestre, alvos de fosforitos, Grupo Bambuí, urânio.

\footnotetext{
${ }^{1}$ Al. Praia de Tramandaí, 369 ap. 108, Stella Maris, 41600-480 Salvador, BA, Brazil. Phone: +55(71) 9327-5045 - E-mail: chrisfianco@hotmail.com

${ }^{2}$ Universidade de Brasília, Instituto de Geociências, Campus Universitário Darcy Ribeiro, Asa Norte, P.0. Box 04465, 70910-900 Brasília, DF, Brazil. Phone: +55(61) 8132-7417 - E-mail: roberta@unb.br

${ }^{3}$ Universidade de Brasília, Instituto de Geociências, Campus Universitário Darcy Ribeiro, Asa Norte, P.O. Box 04465, 70910-900 Brasília, DF, Brazil. Phone: +55(61) 9982-6063 - E-mail: acbpires@unb.br
} 


\section{INTRODUCTION}

The radioelements abundance varies in the Earth's crust, but reported average values range from 2 to $3 \mathrm{ppm}$ for uranium; 8 to $12 \mathrm{ppm}$ for thorium; and, 2 to $2.5 \%$ for potassium, according to Dickson \& Scott (1997), Minty (1997) and IEAE (2003).

Some studies show a direct correlation between the presence of phosphate and high gamma ray spectrometry values. Further studies conducted in phosphate added soils (Souza \& Ferreira, 2005; Becegato \& Ferreira, 2005; Nascimento et al., 2008) show that $\mathrm{K}$, Th and $\mathrm{U}$ radioelements remain in the processed products, increasing the overall count compared to the native soil.

Studies in Syria (e.g. Ashfahani, 2002) also showed that gamma spectrometry is a great tool for phosphate prospection, since interpretation of radiometric surveys in boreholes demonstrates good correlation between eU and $\mathrm{P}_{2} \mathrm{O}_{5}$ contents. The same author also reported that radioactivity intensity in phosphorite layers ranged between 130 and $383 \mathrm{cps}$, with a mean of $270 \mathrm{cps}$ and standard deviation of $57 \mathrm{cps}$.

In Al-Jalamid deposit, Saudi Arabia, Wynn (1996) established in boreholes the relationship between gamma rays counts and phosphate levels, providing a rapid, in-depth evaluation of phosphate resources.

The study area, in northeastern Goiás and southeastern Tocantins, is about $330 \mathrm{~km}$ from Brasília. This N-S elongated area, of approximately $7,000 \mathrm{~km}^{2}$, comprises cities such as Campos Belos, Monte Alegre de Goiás, Nova Roma in Goiás and Arraias in Tocantins.

The Bambuí Group sedimentation, in the Brasilia Belt, began with diamictite during a glacial period. Ice melting allowed the installation of an epicontinental marine environment, and initiated the deposition of pelitic-carbonate sediments that overlap the São Francisco Craton. The environment created due to the deglaciation also established the necessary climatic conditions for the deposition of the phosphatic sediments in the region (Dardenne, 1978).

The geology used in this work (Fig. 1) is the compilation of the geological surveys of the Monte Alegre de Goiás, Nova Roma and Cavalcante sheets, in 1:100,000 scale, held by the Geology Program of Brazil (PGB) of the Geological Survey of Brazil (CPRM) in 2006 (Moreira et al., 2008). A striking feature that can be observed in the area is the differentiation of igneous rocks (basement) in the western portion, and sedimentary rocks in the eastern portion of the area.

The study area can be walked without difficulty due to sparse vegetation. The semiarid climate is responsible for the existence of a mantle of alteration rather thin and discontinuous, which favors the occurrence of rocky outcrops. Ferreira et al. (1992) reported that limestone rocks generally have low levels of radioactive elements. This would allow a contrast of mineralized rocks in the region, since apatite usually has a high eU and eTh content relative to the host rocks (limestone).

Ground geophysics data acquisition was performed between March 4 and 21, 2010; using gamma spectroscopy to measure mean levels of $\mathrm{K}$, eTh, eU and total count.

The survey was conducted along pre-selected profiles based on the results obtained for the mapping of anomalous areas of phosphorus (Fig. 2a) and uranium (Figs. 3 and $2 b$ - the latter taking into account the presence of fluorine), from results obtained by processing publicly available data from airborne geophysics, stream sediment geochemistry and geology of the region (Fianco et al., 2012).

The five profiles (Fig. 3) selected and implemented satisfied different selection criteria. The first was plotted against uranium, fluorine and phosphorus anomalies, mapped based on multiple regression of geophysical and geochemical data (Fianco et al., 2012), although these data were inserted into only one mapped lithology. Similarly, the second profile presented anomalous features of uranium, fluorine and phosphorous, but with different lithologies. The third profile, according to geological mapping carried out by the Itafós Mineração Company (unpublished), shows a lithology of just siltstone, but with anomalies in the maps of estimated uranium and fluorine. The fourth profile, plotted on siltstone, was selected based on its anomalous fluorine and phosphorus signature, showing no anomalous uranium features. The fifth profile was plotted in an area near a mine (in Tocantins state), over siltstone and phosphorite mapped by Itafós, along a line where geochemical information already existed. This last region is not covered by the airborne geophysical data used to generate the map shown in Figure 3.

\section{DATA ACQUISITION}

The gamma spectrometer used for the survey was the GR320 , with a detector of sodium iodide activated with thallium (Nal(TI)) measuring $75 \mathrm{~mm}$ in diameter and $75 \mathrm{~mm}$ thickness. It has a resolution of 256 channels, and an internal cesium source for system stabilization (Exploranium, 2007). The equipment belongs to the Laboratory of Applied Geophysics (LGA), Universidade de Brasília (UnB), and undergoes regular maintenance and calibration by the laboratory's technicians.

A total of approximately 10,712 meters were profiled, with sampling interval of 20 meters, totaling 527 stations (Table 1). Reading time was 300 seconds at each station, as recommended by the radiometric mapping guide (IAEA, 2003). 


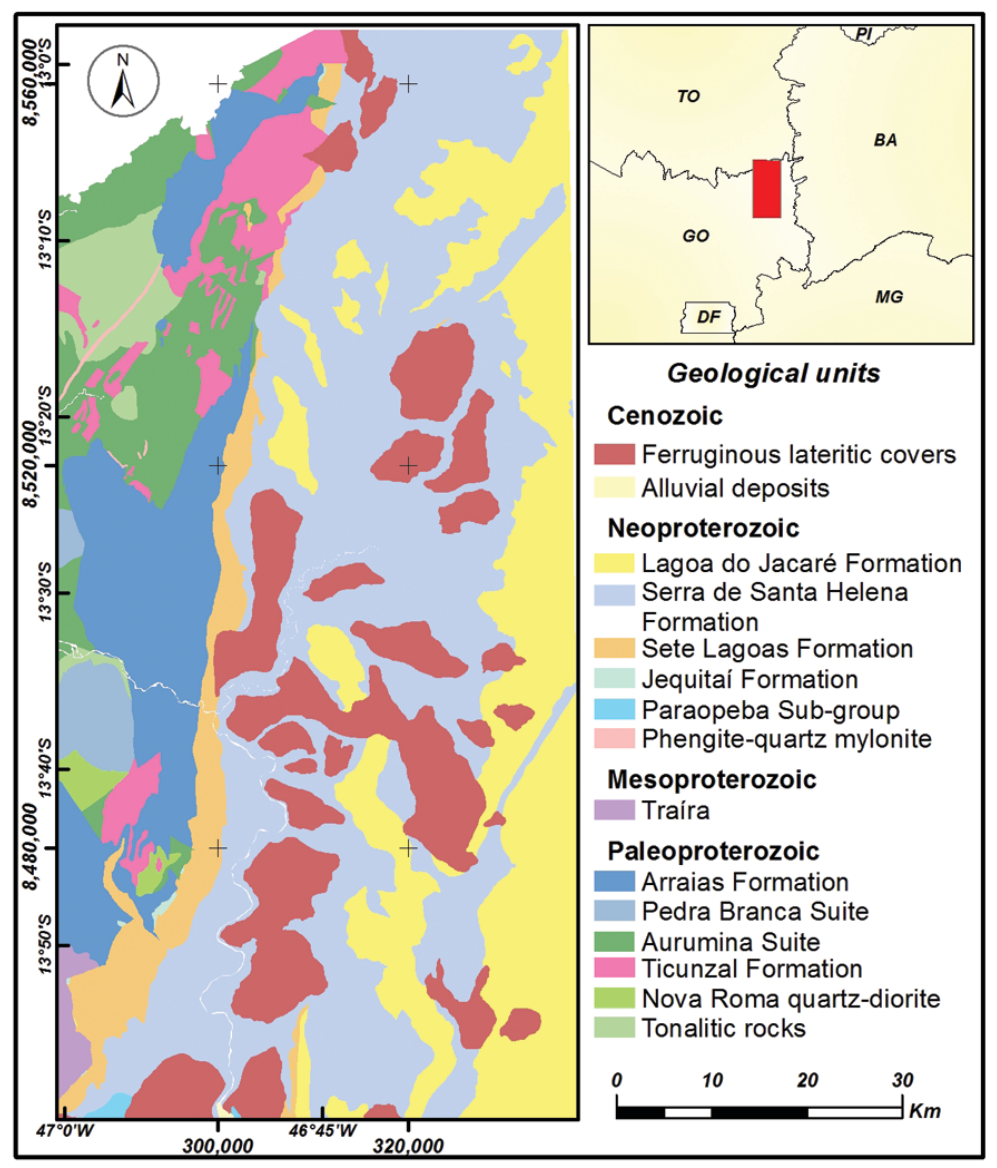

Figure 1 - Geological map of the study area (modified from Moreira et al., 2008).

Radioelements ( $\mathrm{K}$, Th and $\mathrm{U}$ ) are detected by measuring the energy emitted during their decay, where one or more products of the decay chain are partially or completely removed or added to the system. Thorium is rarely found in equilibrium in nature and there is no potassium disequilibrium. Uranium disequilibrium, however, is common, and can occur at various positions in the ${ }^{238} \mathrm{U}$ decay chain: ${ }^{238} \mathrm{U}$ can be selectively transformed to ${ }^{234} \mathrm{U}$ and vice versa, ${ }^{230} \mathrm{Th}$ and ${ }^{226} \mathrm{Ra}$ may be selectively removed from the decay chain, and finally ${ }^{222} \mathrm{Rn}$ (gas) is mobile and can escape from the soil and rocks to the atmosphere. It can take days, months or even millions of years for equilibrium to be reached, depending on the half-life of the isotopes involved (IAEA, 2003).

For these reasons, the uranium series is a source of error in gamma spectrometry. Uranium concentrations are calculated by measuring the isotopes ${ }^{214} \mathrm{Bi}$ and ${ }^{214} \mathrm{~Pb}$. These are far down the radioactive decay chain and may not be in equilibrium with $U$. Uranium concentration estimates are then reported as "equivalent uranium" (eU) in parts per million (ppm), since these estimates assume equilibrium conditions. Thorium is also usually reported as "equivalent thorium" (eTh) in ppm, despite the fact that thorium series is almost always in equilibrium (IAEA, 2003).

Potassium concentrations are calculated in a straightforward manner from ${ }^{40} \mathrm{~K}$ gamma ray emission and the result is reported as a percentage (\%). The small differences between the values obtained during the survey in cps, ppm and \% can be observed in the graph (Fig. 4) and profile 1 table (Table 1).

Table 1-Information of ground profiles like: extension and number of stations in each.

\begin{tabular}{|c|c|c|}
\hline Profile & $\begin{array}{c}\text { Extension } \\
(\mathrm{m})\end{array}$ & $\begin{array}{c}\text { Number } \\
\text { of stations }\end{array}$ \\
\hline Profile 1 & 3,885 & 197 \\
Profile 2 & 1,688 & 82 \\
Profile 3 & 3,709 & 179 \\
Profile 4 & 850 & 41 \\
Profile 5 & 580 & 28 \\
Total & 10,712 & 527 \\
\hline
\end{tabular}

Taking into account that radioelements concentrations may be susceptible to environmental, pedogenic, geomorphological and 

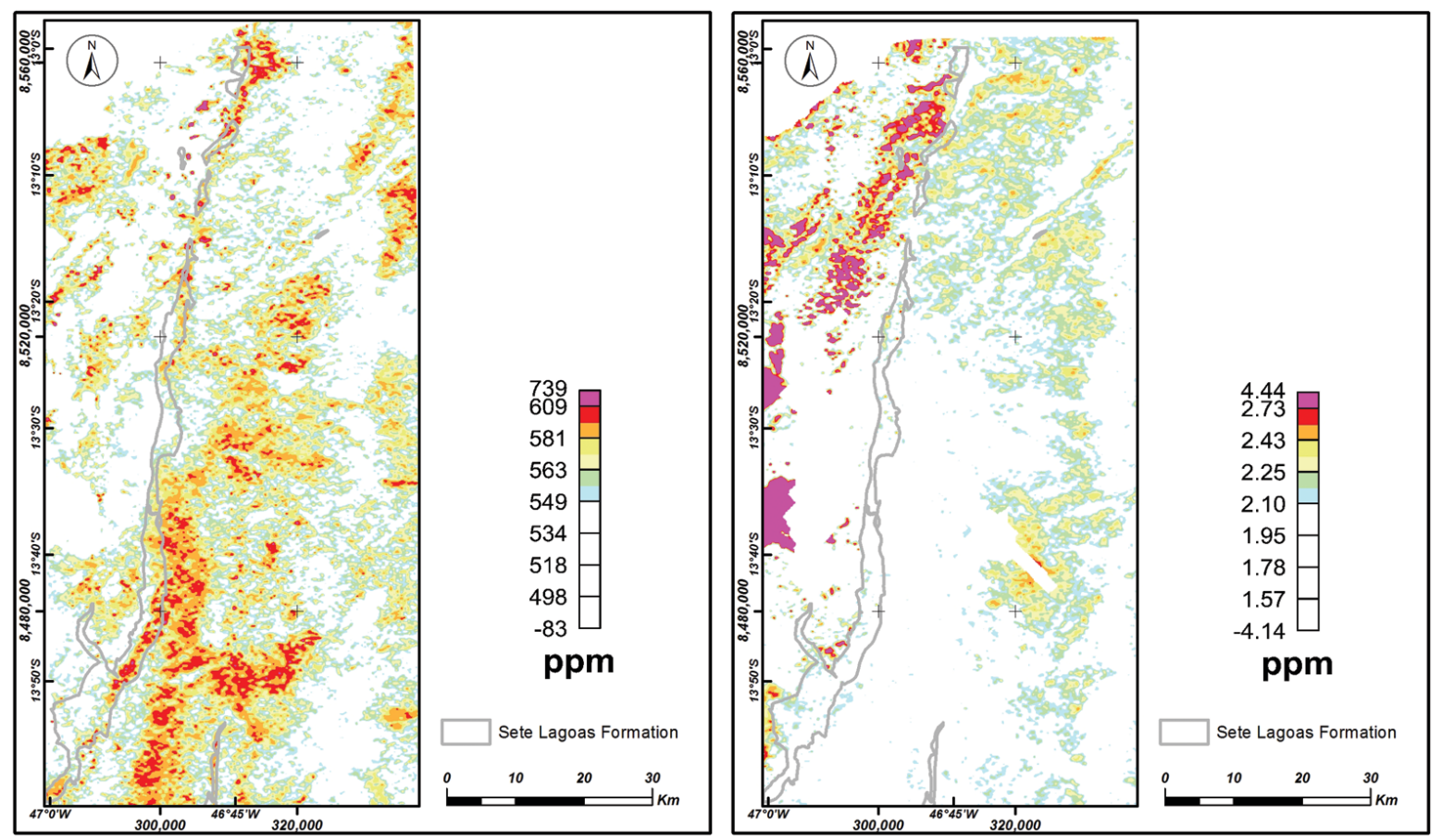

Figure 2 - a) Map of Phosphrous estimates in ppm, results from linear regression equation of $P$ related to $e U, K, e T h$, eU/eTh, eU/K, eTh/K and ASA. b) Map of Uranium estimates in ppm, results from linear regression equation of $\mathrm{U}$ related to $\mathrm{K}, \mathrm{eTh}, \mathrm{eU}$, eU/eTh, eU/K, eTh/K, ASA, $\mathrm{P}$ and $\mathrm{F}$.

geochemical effects, and lithological variations (e.g. Dickson \& Scott, 1997), we took care to avoid the rainy season, drainage areas and maintain always the same distance $(\sim 30 \mathrm{~cm})$ between the equipment and the terrain.

According to verbal information provided by geologists of Mineração Itafós, the mineralized bodies in the region extend, in general, up to $100 \mathrm{~m}$ long and about $40 \mathrm{~m}$ wide with preferential NW-SE direction. The 20-m spacing between stations was set to ensure at least one sampling point on them, and good data spatial distribution.

\section{DATA ANALYSIS}

The acquired gamma ray spectrometric data presented and discussed here are based on the radioelements profiles, eTh and eU expressed in ppm (parts per million) and $\mathrm{K}$ in percentage (\%), the total count in cps (counts per second) and eU/K and eU/eTh ratios. The ratios were calculated after analyzing the correlation between the profiles of each element, where an inverse correlation between potassium and uranium data was observed.

Figure 4 shows the results for $\mathrm{K}$, eTh, eU and CT, in cps; $\mathrm{K}$, in \%; and eU and eTh, in ppm, in order to show the good correlation obtained between the results. Figure 4 shows these correlations for profile 1 data, but the good correlation observed in this profile is also observed in all the rest. The good correlation observed shows that the instrument was calibrated.

Relying on the correlation between $\%$ and ppm found in the literature regarding these radioelements concentrations in the crust, we chose to work with the transformed data, i.e. in ppm and \%.

\section{PROFILE 1}

Profile 1 is 3,885 meters long, E-W trending, in the south-central portion of Figure 3. This profile has been plotted based on eU, $\mathrm{F}$ and $\mathrm{P}$ anomalies mapped by airborne data processing (Fianco et al., 2012) and integrated with stream sediment geochemistry data of SIG Goiás (Moreira et al., 2008). Furthermore, there is a geochemical analysis point of this stream sediment close to the profile with $\mathrm{P}$ value greater than $600 \mathrm{ppm}$ (Moreira et al., 2008). Topographic variation is small and vegetation almost exclusively pastures throughout almost the entire profile. The profile crosses a small stream at the eastern end (indicated by the blue arrow, Fig. 5a). This profile has no known mineralization.

The lithology, shown at the upper part of Figure 5, is constituted predominantly by siltstone, which occurs at the beginning (west), limestone blocks (not mapped, but identified in the field), and localized portions with laterization features identified in the field. 


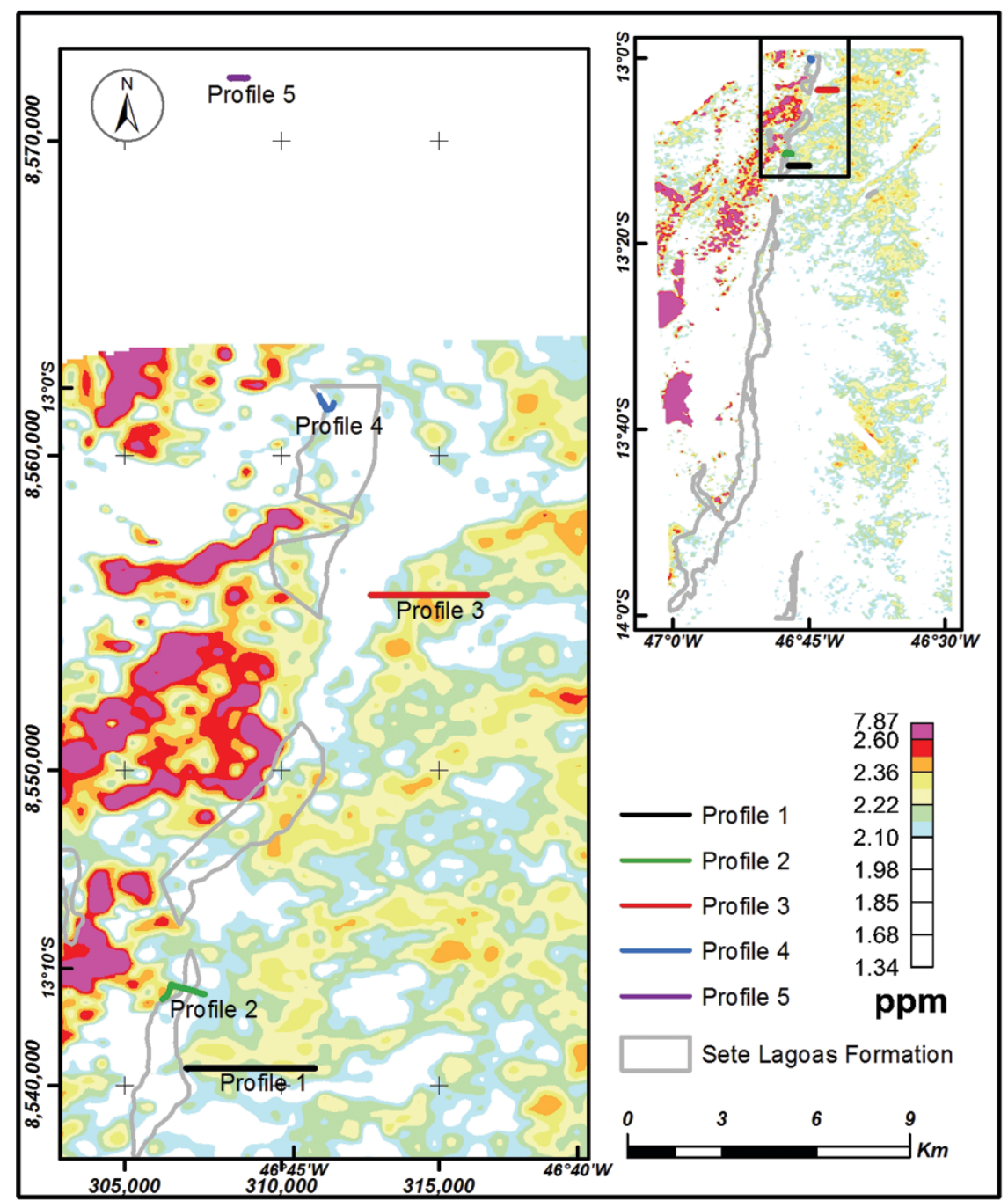

Figure 3 - Map of uranium estimates and geochemical points with $\mathrm{P}$ content over $600 \mathrm{ppm}$, and the localization of the 5 ground profiles of gamma ray acquisition. There is no data information in the area over profile 5.

Figure 5 shows the post-processed data of eU, eTh and K; the eU/eTh and eU/K ratios; and total count (cps). Table 2 shows the minimum, maximum, mean and standard deviation values of the radioelements along Profile 1.

Table 2 - Statistical data of field survey for Profile 1.

\begin{tabular}{|c|c|c|c|c|}
\hline & $\begin{array}{c}\mathrm{K} \\
(\%)\end{array}$ & $\begin{array}{c}\text { Th } \\
(\mathrm{ppm})\end{array}$ & $\begin{array}{c}\mathrm{U} \\
(\mathrm{ppm})\end{array}$ & $\mathrm{TC}$ \\
\hline Minimum & 0.3 & 7.1 & 1.4 & 9.4 \\
Maximum & 2.9 & 18.6 & 4.9 & 22.7 \\
Average & 1.36 & 13.76 & 3.16 & 17.65 \\
Standard deviation & 0.50 & 2.13 & 0.65 & 2.55 \\
\hline
\end{tabular}

Along the profile, $\mathrm{K}$ content (Table 2) varies from $0.3 \%$ to $2.9 \%$, with an average of $1.36 \%$, which is below the crust av- erage of $2.5 \%$. The profile of $\mathrm{K}$ (Fig. 5a) shows a fairly obvious feature in the central, flat region, with values around $1 \%$ bordered by values that rise abruptly up to $3 \%$. In other regions, $\mathrm{K}$ concentration ranges between 1 and 2.9 percent, reaching values slightly above the calculated crust average (2.5\%), with the lower values occurring at the beginning of the profile (west).

The eTh profile (Fig. 5b) shows an irregular pattern, with concentration ranging between 7 and 18 ppm (Table 2), and, in general, with values above the average eTh values in the crust (8$12 \mathrm{ppm}$ ). The eU profile (Fig. 5c) has also an irregular pattern, with values ranging between 1 and 5 ppm (Table 2). In the central region, however, two subtle enrichment peaks can be observed (about $5 \mathrm{ppm}$ ). These two profiles illustrate well the flooded areas, since the values of the elements decline significantly. 


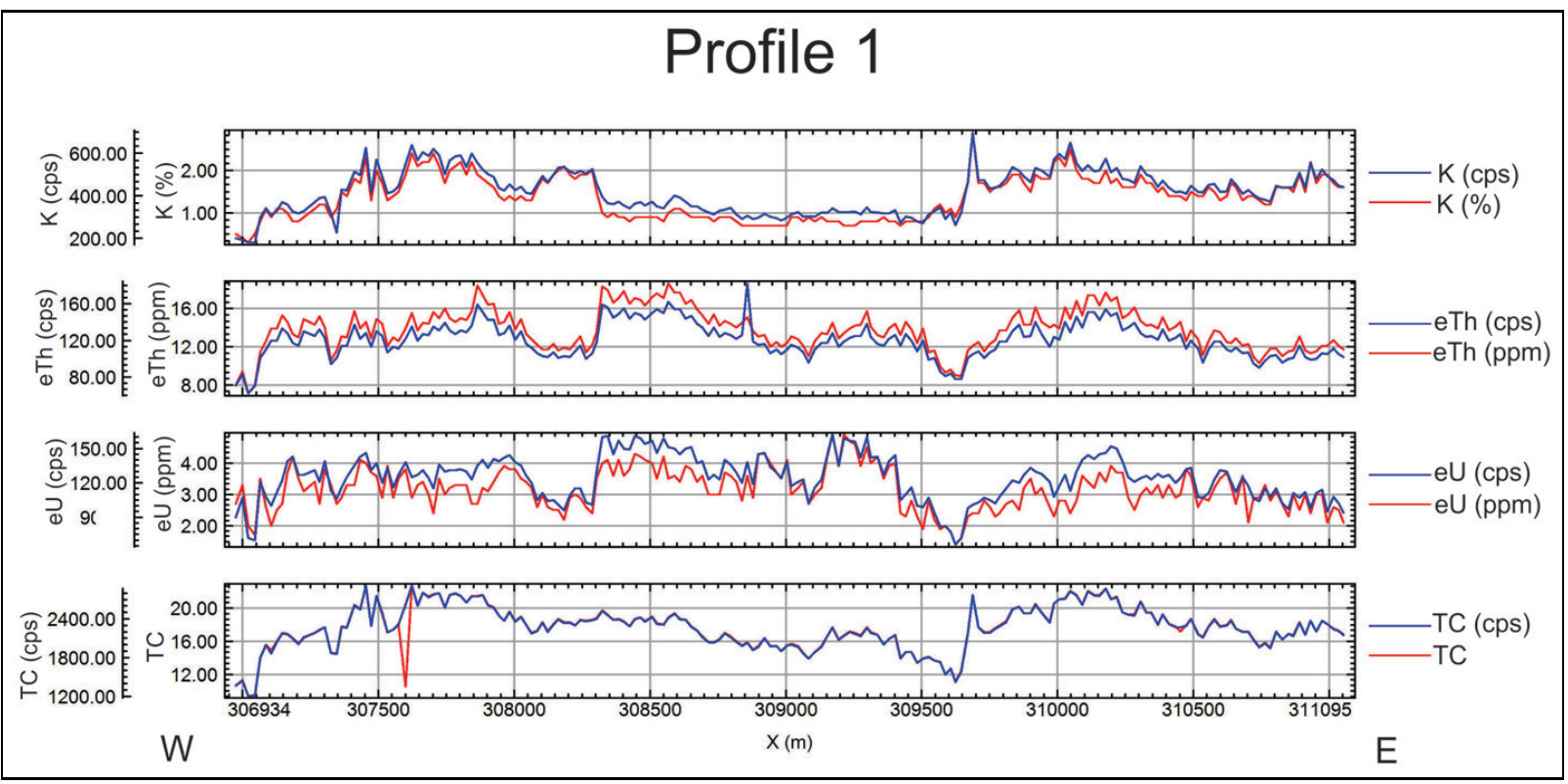

Figure 4 - Comparison profiles of radioelement values of $\mathrm{K}$, eTh, eU and total count acquired in the field, with values in cps (counts per second), percentage (\%) and ppm (parts per million).

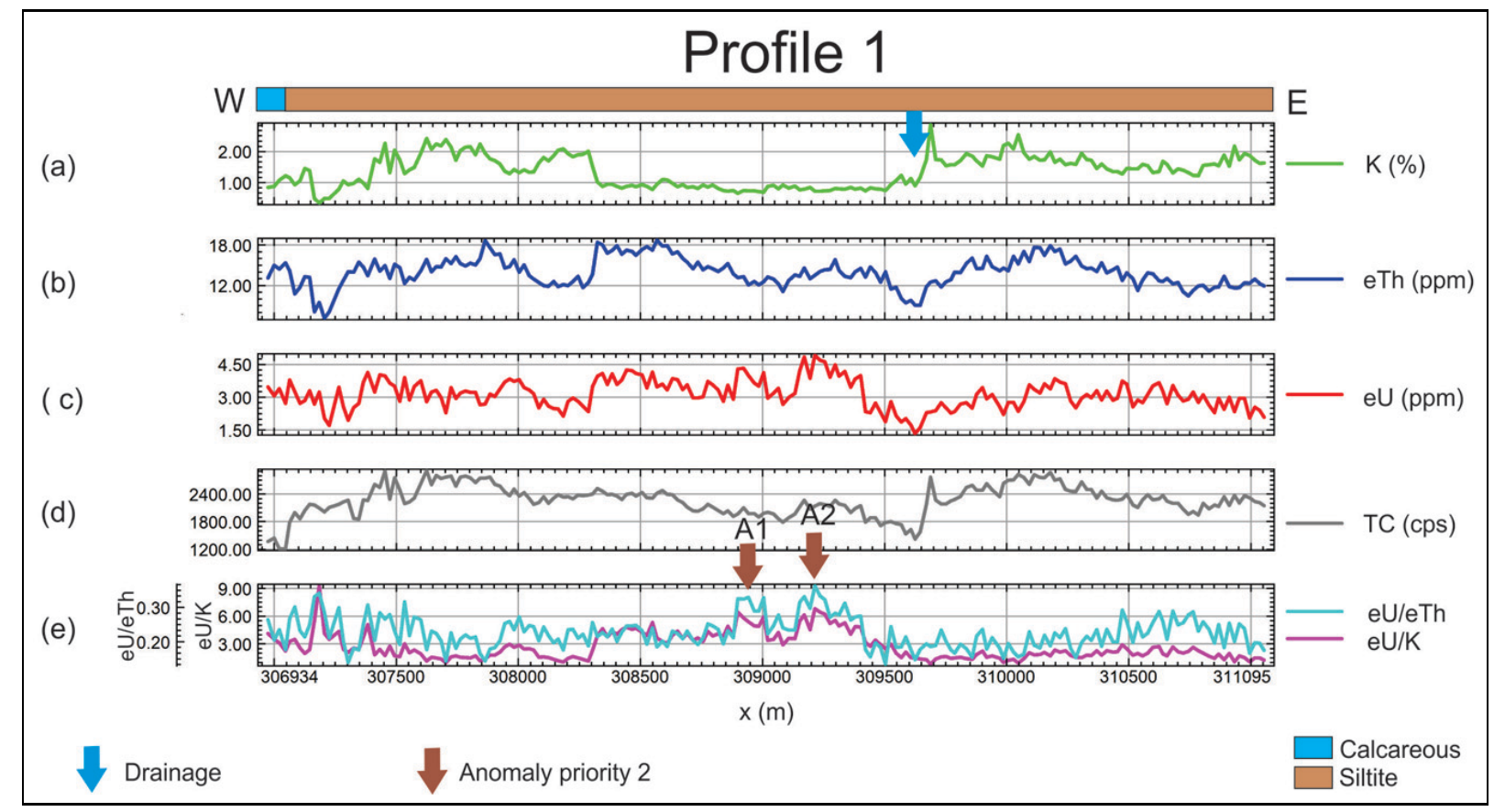

Figure 5 - Profiles of radioelement values of K (a), eTh (b), eU (c) and total count (d) acquired in the field, and eU/eTh and eU/K ratios (e) for Profile 1. The blue arrow indicates the presence of a stream, and the brown arrows indicate anomalous features (A1 and A2). 
The total count profile has two significant lows (Fig. 5d); the first towards the west, where there is occurrence of limestone and the second near the coordinate $309500 \mathrm{~m}$ east, where there is a stream.

Two main peaks can be easily identified in the eU/K and eU/eTh profiles (Fig. 5e), indicated by $\mathrm{A} 1$ and $\mathrm{A} 2$ arrows, in which the levels of uranium in relation to eTh and $\mathrm{K}$ are high (above 0.3 and above 7 , respectively). These points were selected for field check with priority 1 .

Despite only one lithology being mapped along almost the entire profile, with the exception of the limestone in the beginning, there are large variations in radioelements concentration; like the region where the low $\mathrm{K}$ values (Fig. 5a) correlates with the two eU peaks (Fig. $5 \mathrm{C}$ ). The two peaks (A1 and A2) could possibly be explained by the presence of lateritic concretions found in this region.

\section{PROFILE 2}

Profile 2 is 1,688 $\mathrm{m}$ long and was traced because it crosses different lithologies, including one phosphorite mapped by Itafós. This area does not have any points of anomalous $P$ geochemistry (Moreira et al., 2008). However, anomalous eU, $F$ and $P$ features were mapped (cut by the profile) using the multiple regression method, in which geophysical and geochemical information were integrated. The profile was planned as a straight $\mathrm{E}-\mathrm{W}$ line, but it was modified (green profile in Fig. 3) due to lack of authorization to open pathways by the landowner.

The profile geology varies from $W$ to $E$, starting with silty-clay soil, followed by a zone of schist faults with quartz pebbles, and then followed by siltstone. These rock types are represented in plan view at the top of Figure 6 . Figure $6 \mathrm{~d}$ also shows phosphorite outcrops, mapped by Itafós, intercepted by the profile in two regions.

Figure 6 shows the post-processed data of radioelements $\mathrm{eU}$, eTh and $\mathrm{K}$; the total count (cps), and eU/eTh and eU/K ratios for profile 2. Table 3 shows the minimum, maximum, mean and standard deviation values of the radioelements in this profile.

Table 3 - Statistical data of field survey for Profile 2.

\begin{tabular}{|c|c|c|c|c|}
\hline & $\begin{array}{c}\mathrm{K} \\
(\%)\end{array}$ & $\begin{array}{c}\text { Th } \\
(\mathrm{ppm})\end{array}$ & $\begin{array}{c}\mathrm{U} \\
(\mathrm{ppm})\end{array}$ & $\mathrm{TC}$ \\
\hline Minimum & 0.4 & 4.6 & 1 & 10.2 \\
Maximum & 3.6 & 15.7 & 4.8 & 26.1 \\
Average & 1.7 & 9.81 & 2.62 & 16.30 \\
Standard deviation & 0.62 & 3.24 & 0.86 & 3.24 \\
\hline
\end{tabular}

The $\mathrm{K}$ profile (Fig. 6a) averages between 1.5 and $2 \%$, below the crust average (2.5\%). However, a peak concentration of

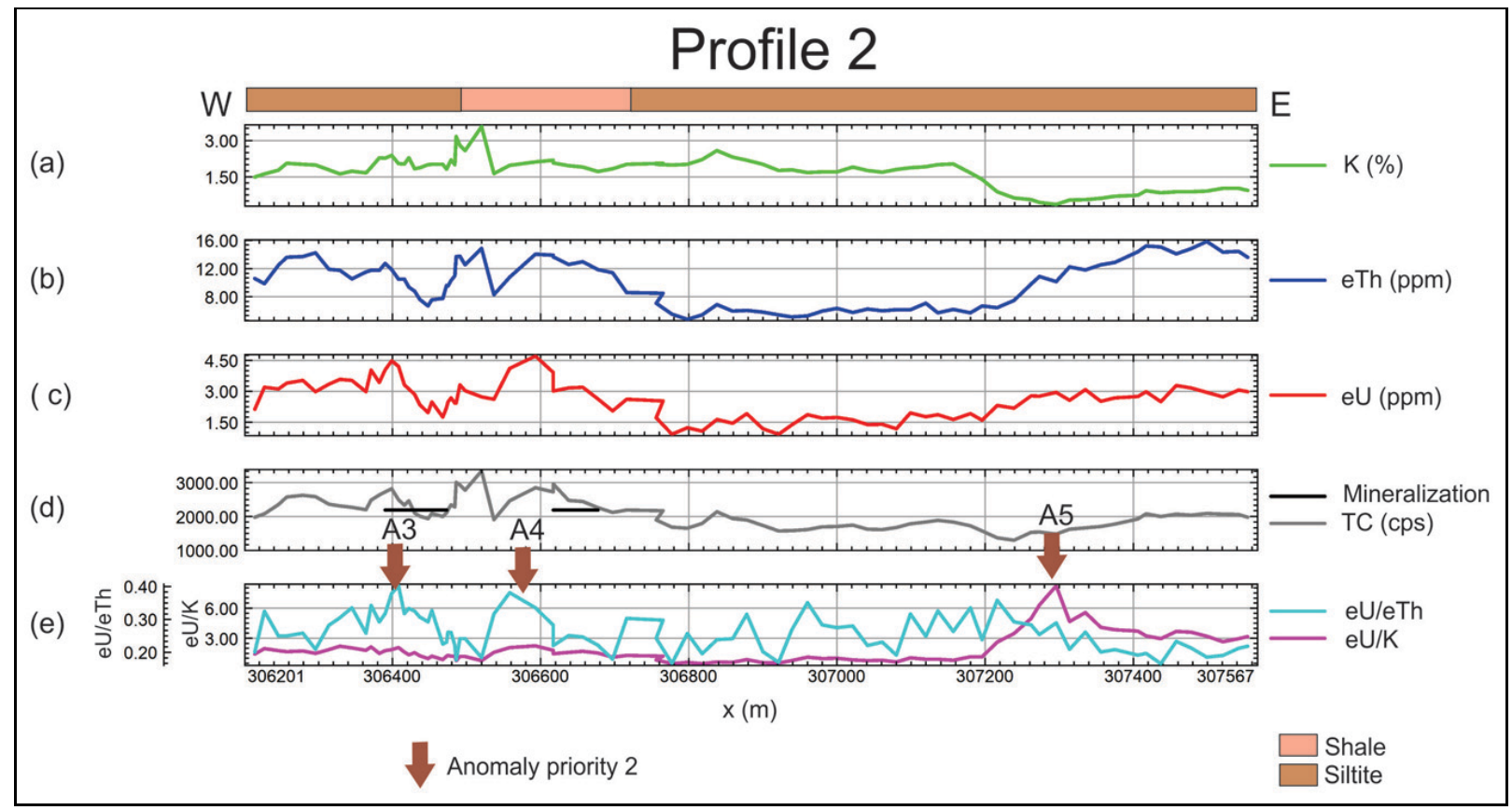

Figure 6 - Profiles of radioelement values of K (a), eTh (b), eU (c) and total count (d) acquired in field, and eU/eTh and eU/K ratios (e) for Profile 2. The brown arrows indicate anomalous features in the area (A3, A4 and A5). 
almost $4 \%$ can be observed around the coordinate east $306500 \mathrm{~m}$, which we correlated with the dolomite of Sete Lagoas Formation. The values of $K$ decrease significantly in the last 300 meters of the profile (east), an area dominated by siltstones.

Thorium varies between 4 and 16 ppm throughout the profile (Fig. 6b). At the beginning the values are more expressive, especially a well-marked peak (the same peak observed in the $\mathrm{K}$ profile) with concentrations of about $15 \mathrm{ppm}$, above the crust average (8-12 ppm). After this stretch, the concentration decreases for nearly 400 meters to 5 ppm average. In the final part of the profile the content rises considerably, reaching once more values up to $16 \mathrm{ppm}$.

Uranium (Fig. 6c) profile is similar to thorium (Fig. 6b). The average value of the western portion is higher ( $3 \mathrm{ppm})$, declining in the central portion and increasing slightly in the eastern portion. Still, two peaks (306400 m and $306600 \mathrm{~m}$ ) reaching relatively high values up to $4.5 \mathrm{ppm}$ are evident in the initial part.

Total count profile (Fig. 6d) shows a more regular behavior, with less significant, but no less important variations. The first half (western portion) of profile 2 (Fig. 6) has at least three major peaks: one more pronounced central peak at $306500 \mathrm{~m}$ and two lateral (indicated by brown arrows) with relevant importance, considering the presence of mineralized bodies, mapped by Itafós and marked on the total count profile (TC) with black lines (Fig. 6d). The second half (eastern) presents a more constant behavior with no significant features.

The eU/K profile (Fig. 6e) behaves more regular, with a noticeable peak in the last quarter (east), indicated by arrow A5 (Fig. 6e). The eU/eTh profile (Fig. 6e) shows an irregular pattern, with many highs and lows, and two relevant peaks (values 0.4 ), identified by arrows $\mathrm{A} 3$ and $\mathrm{A4}$ (Fig. 6e), coincident with the mineralized areas. These points are indicated for field verification.

A careful analysis of the two mapped mineralization regions and the radioelement profiles shows an offset of a few meters between mineralization (black lines in CT profile) and uranium peaks with more than 3 ppm (Fig. 6c). Furthermore, the eU/eTh profile (Fig. 6e) also shows relatively high values of eU and eTh. The $\mathrm{A} 5$ peak, on the eU/K profile (equal to 8 , in Fig. 6 e), requires further investigation.

\section{PROFILE 3}

Profile 3 is 3,709 m long on E-W direction, cutting two distinct lithologies according to the geological map (Moreira et al., 2008). But, this region is formed only by siltstone according to the mapping done by Itafós. This profile crosses $F$ and eU anomalies, quite evident in the maps, and has no P related anomaly (red profile in Fig. 3). The profile is located almost exclusively in pasture area, crossing a marsh on the eastern end.

The geology along this profile is quite monotonous, mainly with silty lithology and only minor compositional and coloring variations (Fig. 7). The topography does not vary much along the profile, and the vegetation is varied; pasture, forest and deforested areas.

Figure 7 shows the post-processed data of eU, eTh and K; total count (cps), and eu/eTh and eU/K ratios. Table 4 shows the radioelements maximum, minimum, average and standard deviation values along profile 3 .

Table 4 - Statistical data of field survey for Profile 3.

\begin{tabular}{|c|c|c|c|c|}
\hline & $\begin{array}{c}\mathrm{K} \\
(\%)\end{array}$ & $\begin{array}{c}\text { Th } \\
(\mathrm{ppm})\end{array}$ & $\begin{array}{c}\mathrm{U} \\
(\mathrm{ppm})\end{array}$ & $\mathrm{TC}$ \\
\hline Minimum & 0.1 & 10.4 & 0.6 & 8.7 \\
Maximum & 1.8 & 21.6 & 5.3 & 22 \\
Average & 0.95 & 16.91 & 3.44 & 18.04 \\
Standard deviation & 0.41 & 2.4 & 0.85 & 2.0 \\
\hline
\end{tabular}

$\mathrm{K}$ (Fig. 7a) has a low concentration at the beginning of the profile (western part), reaching about $0.8 \%$, with some peaks of $1.6 \%$ at the center and end of the profile. All values are below average crust concentration (2.5\%). In the region indicated by the blue arrow, $\mathrm{K}$ levels decline abruptly, showing clearly the presence of water.

The eTh values do not change significantly over the entire profile 3 (Fig. 7b), with the exception of the marsh area (indicated by blue arrow), where the values decrease from $10 \mathrm{ppm}$ to nearly $0 \mathrm{ppm}$. The average eTh levels along the profile are about $15 \mathrm{ppm}$, above the average values of the crust (8-12 ppm).

Like in profile 3b, uranium profile (Fig. $7 c$ ) does not vary significantly, except in the last 500 meters, where values tend to zero in the marsh region. Uranium levels along the profile average more than $3 \mathrm{ppm}$, considered high for the element since it averages 2 ppm in the Earth's crust.

Total count (Fig. 7d) shows more obvious variations at the beginning and end of the profile (West and East, respectively) where the radioelements concentrations are lower, and in the central portion where the values increase, but with no apparent peaks.

The eU/eTh profile (Fig. 7e) shows a rather regular behavior with only one low in the marsh area, and a high at the beginning, but nothing very significant. The eU/K profile (Fig. 7e) presents an anomalous early portion (west), with higher values and a peak, indicated by the brown arrow A6 (Fig. 7e). In this region, enrichment of uranium compared to potassium can be observed. 


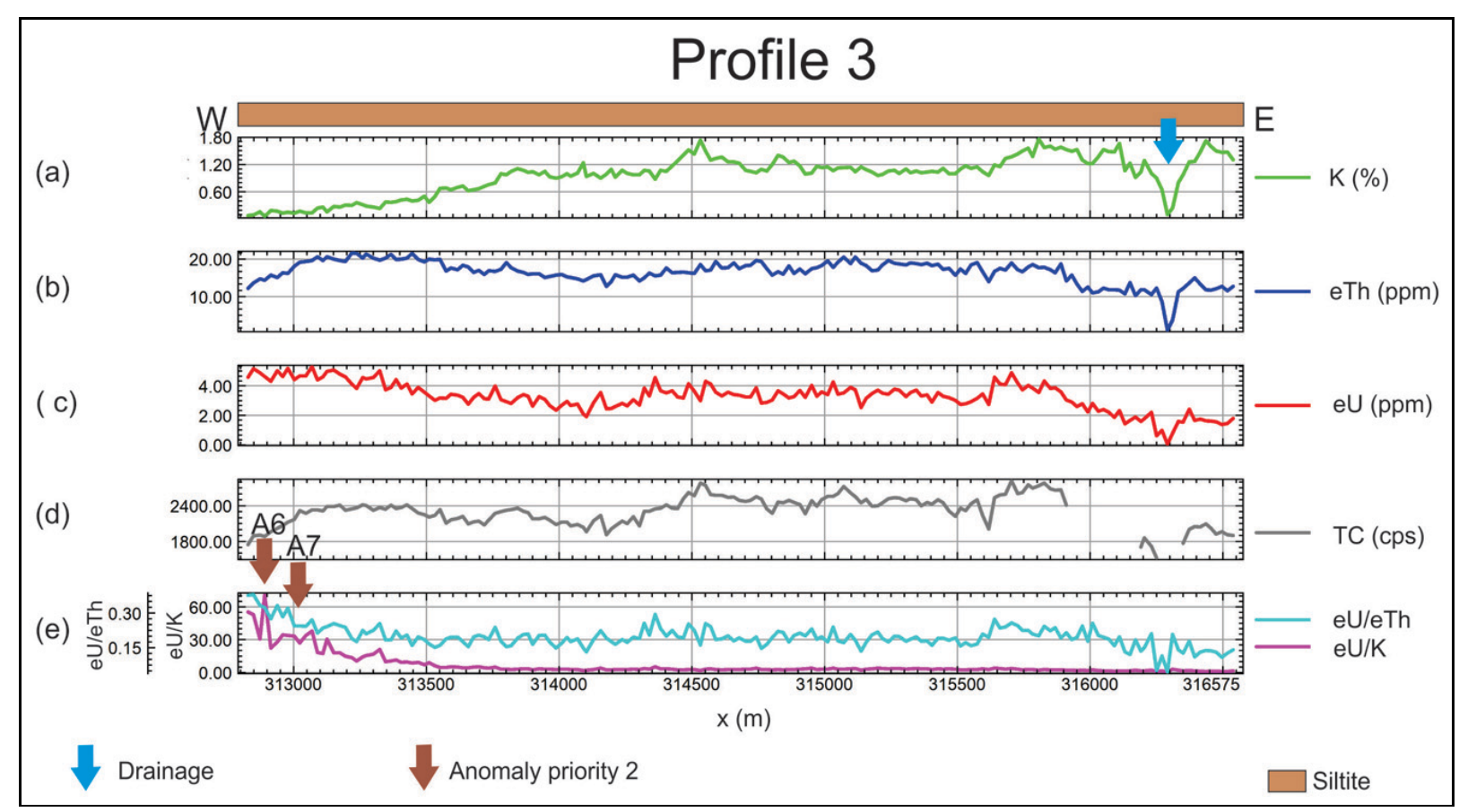

Figure 7 - Profiles of radioelement values of $\mathrm{K}(\mathrm{a})$, eTh (b), eU (c) and total count (d) acquired in the field, and eU/eTh and eU/K ratios (e) for Profile 3. The blue arrow indicates a marsh region, and the brown arrows anomalous features in the area (A6 and A7).

In the beginning of the western portion of the profile, for approximately 700 meters (Fig. 7c), the eU levels are about 4 ppm, and $\mathrm{K}$ levels are almost zero. Despite the known mineralized bodies in the region having extensions smaller than 100 meters, this region, marked with arrow A7 (Fig. 7e), also shows an interesting pattern with high eU/eTh and eU/K values compared to known mineralization areas, something worthy of further field investigation.

The lack of information in some segments of the total count (cps) profile (Fig. 7d) corresponds to periods when analog recording of data was not possible, due to a momentary problem in the equipment's display.

\section{PROFILE 4}

Profile 4 is located west of Mineração Itafós and extends $850 \mathrm{~m}$ (blue profile in Fig. 3). The profile, first drawn with E-W direction, was modified to run along existing secondary roads due to problems with the landowner. The survey intersects mapped fluorine and phosphorus anomalies, but no uranium anomalies. The profile is near a geochemical sampling point with $P$ value above $600 \mathrm{ppm}$.

This profile cuts mainly silty soil with fragments of siltstone and siltstone outcrops (Fig. 8) with very rugged topography. The survey was conducted along the secondary road that runs through the area. There is a phosphorite body mapped by Itafós in the region (Fig. 8d).

Table 5 - Statistical data of field survey for Profile 4.

\begin{tabular}{|c|c|c|c|c|}
\hline & $\begin{array}{c}\mathrm{K} \\
(\%)\end{array}$ & $\begin{array}{c}\mathrm{Th} \\
(\mathrm{ppm})\end{array}$ & $\begin{array}{c}\mathrm{U} \\
(\mathrm{ppm})\end{array}$ & $\mathrm{TC}$ \\
\hline Minimum & 2.1 & 10.8 & 2 & 19.4 \\
Maximum & 3.7 & 14.6 & 3.6 & 26.1 \\
Average & 3.10 & 12.78 & 2.73 & 23.45 \\
Standard deviation & 0.31 & 0.75 & 0.34 & 1.40 \\
\hline
\end{tabular}

Profile 4a (Fig. 8) presents a very noticeable $K$ depletion early on (west), while the remainder varies from about $3 \%$ to $3.6 \%$, I0cally. A slight concentration decrease occurs in the region where mineralization is marked (mapped close to the line), only to rise again at the eastern portion.

Thorium falls significantly at the beginning of profile $4 b$, to the west (Fig. 8b), where $\mathrm{K}$ concentration also decreased, but then increases to an average of $13 \mathrm{ppm}$. Near the coordinate $311400 \mathrm{~m}$ east, reaches a peak of $15 \mathrm{ppm}$, and then immediately falls to values between 12.5 and $13.5 \mathrm{ppm}$. Similar to potassium, thorium levels increase again, reaching $15 \mathrm{ppm}$, at the eastern end.

Uranium profile (Fig. 8c) shows an irregular behavior. It has a sharp peak at the beginning of the line (red arrow), as opposed to $\mathrm{K}$ and eTh, justifying the peaks that occur in the ratio pro- 


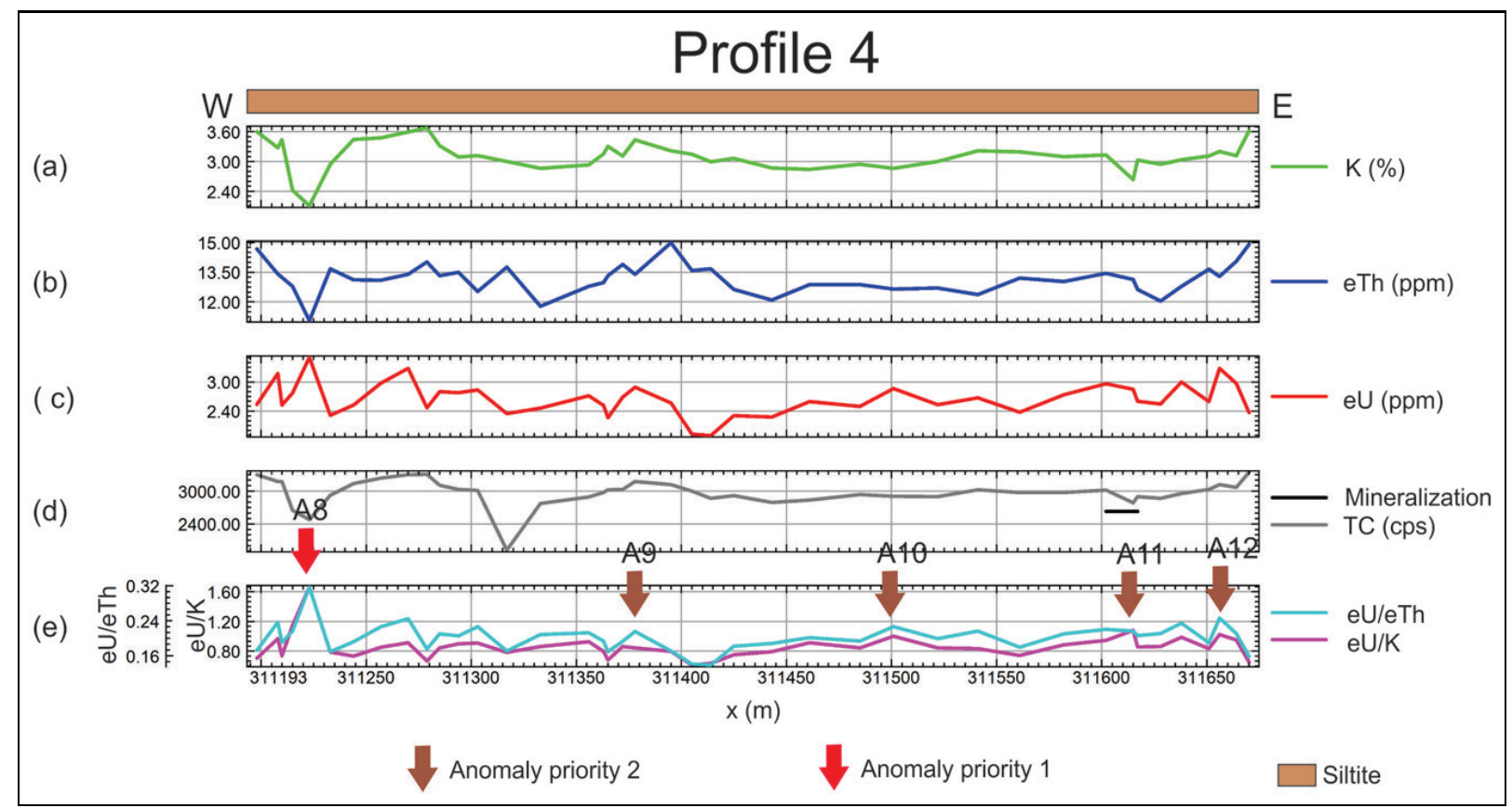

Figure 8 - Profiles of radioelement values of $\mathrm{K}(\mathrm{a})$, eTh (b), eU (c) and total count (d) acquired in the field, and eU/eTh and eU/K ratios (e) for Profile 4. The arrows of this profile indicate anomalous features in the area, the red ones with first priority (A8) of investigation and the brown ones with second priority (A9, A10, A11 and A12).

files listed below. It also has two smaller peaks west and east of this main peak. These three peaks have levels higher than 3 ppm. Moving towards the end of the line (eastern portion) we see variations between 1.6 and 3 ppm, and a new peak above 3 ppm at the eastern end. A slight increase, to about 3 ppm, occurs in the mineralization area.

The total count profile (Fig. 8d) is more constant, with two large depletions, one at the beginning (western portion), where the uranium peaks and $\mathrm{K}$ and eTh lows occur, and the other near the coordinate $311320 \mathrm{~m}$ east. A slight decrease of the radioelements concentrations is also observed in the mineralization region.

In profile 6 of eU/K and eU/eTh ratios (Fig. 8e), a well-marked peak is observed at the beginning of the line (west), indicated by the red arrow A8 (Fig. 8e), and other less obvious peaks along the line marked with brown arrows A9, A10, A11, A12 and A13 (Fig. 8e).

Although the lithology mapped throughout profile 4 is constant, siltstone, profiles of the 3 radioelements ( $\mathrm{K}$, eU and eTh) indicate variations in its composition. As discussed individually, in the region where an ore presence was mapped near the surveyed line, $\mathrm{K}$ values decrease slightly, while eU and eTh values rise slightly, also observed in the ratios profile.

The arrows in the ratios profile (Fig. 8e) indicate field check locations. These peaks indicate enrichment of Uranium in relation to $\mathrm{eTh}$ and $\mathrm{K}$.

\section{PROFILE 5}

Profile 5 is in Tocantins, in an area where Itafós is mining phosphate, but without any information from airborne geophysics. Along this 580-m long profile, E-W trending, 28 measurements were performed. The survey crosses a mapped phosphorite body. This profile was chosen because geochemical soil sampling, and geophysical surveys with GPR and two-dimensional electrical imaging has already been conducted by Itafós.

The geology in Figure 9 determines siltstone as the prevailing lithology along this profile, while there is also a phosphorite body (Fig. 9d) mapped by Itafós. The position indicated by the blue arrow (Fig. 9a) marks a stream that cuts the profile. The area in the western part has a slightly rugged relief with pasture, which becomes thicker vegetation near the stream.

Figure 9 shows the post-processed data of the radioelements eU, eTh and $\mathrm{K}$; total count (cps); and eU/eTh and eU/K ratios. Table 6 shows the minimum, maximum, mean and standard deviation values of the radioelements along Profile 5 .

Potassium profile (Fig. 9a) is marked by a high to the west and a significant drop from halfway the line to the east. Values range from about $4 \%$ in the higher regions, to almost 0 in the lower region, an area with a phosphorite body mapped by Itafós.

The eTh profile (Fig. 9b) shows a pattern quite similar to potassium (Fig. 9a), with the highest values (18 ppm) in the western portion, with a significant decrease in the eastern portion, 


\section{Profile 5}

(a)

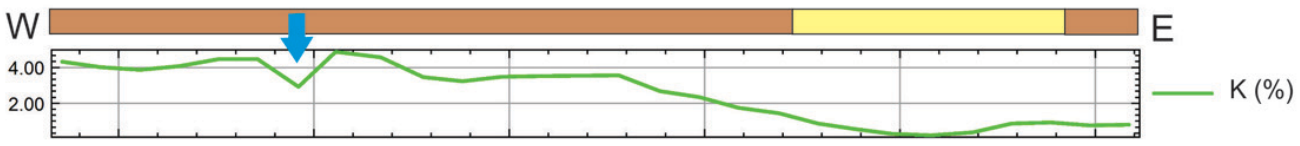

(b)

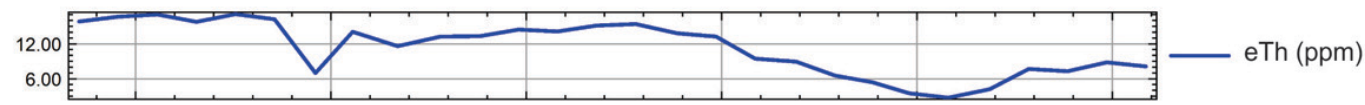

(c)

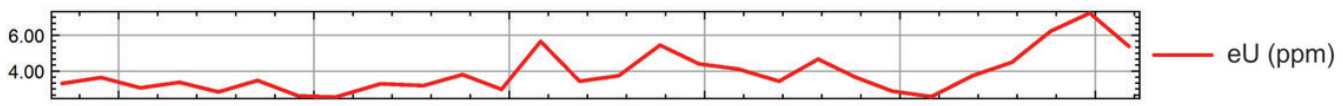

(d)

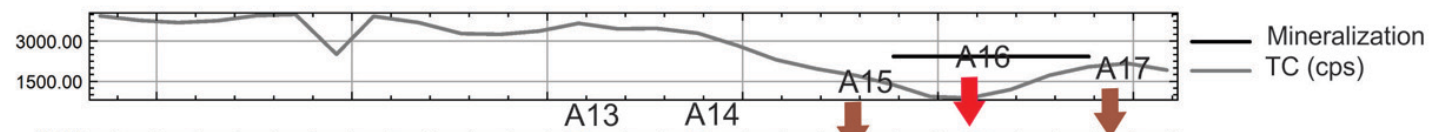

(e)

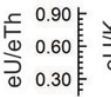

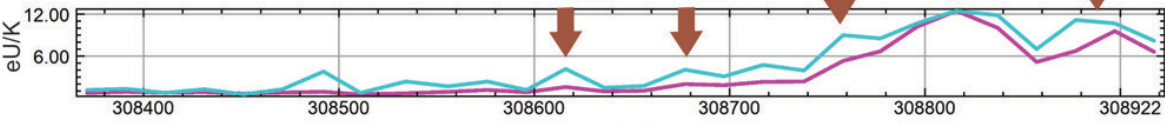

$x(m)$

Drainage

Anomaly priority 2

Anomaly priority 1

eU/eTh

$\mathrm{eU} / \mathrm{K}$

Figure 9 - Profiles of radioelement values of $\mathrm{K}(\mathrm{a})$, eTh (b), eU (c) and total count (d) acquired in the field, and eU/eTh and eU/K ratios (e) for Profile 5 . The blue arrow indicates the presence of a stream in the area, and the other arrows anomalous regions encountered on profiles. The red arrow indicates first priority (A16) of investigation and the brown ones, second priority (A13, A14, A15 and A17).

where it reaches its lowest value of $4 \mathrm{ppm}$ increasing slightly at the end.

The eU profile (Fig. 9c) shows high values over the entire line, ranging from 2 to $7 \mathrm{ppm}$. From the beginning (west) until almost the middle of the survey line, values range between 2 and 4 ppm, showing two peaks of about 6 ppm on the center, marked with brown arrows. There is a less obvious peak near coordinate $308750 \mathrm{~m}$ east. The mapped mineralization area of the region shows a slight decrease in eU values, but these remain high, above $3 \mathrm{ppm}$. At the end of the line, marked by the brown arrow, occurs a peak that reaches approximately $7 \mathrm{ppm}$.

Table 6 - Statistical data of field survey for Profile 5.

\begin{tabular}{|c|c|c|c|c|}
\hline & $\begin{array}{c}\mathrm{K} \\
(\%)\end{array}$ & $\begin{array}{c}\text { Th } \\
(\mathrm{ppm})\end{array}$ & $\begin{array}{c}\mathrm{U} \\
(\mathrm{ppm})\end{array}$ & $\mathrm{TC}$ \\
\hline Minimum & 0.2 & 2.7 & 2.6 & 6.8 \\
Maximum & 4.9 & 16.5 & 7.2 & 31.2 \\
Average & 2.58 & 10.95 & 3.97 & 21.81 \\
Standard deviation & 1.57 & 4.33 & 1.13 & 8.00 \\
\hline
\end{tabular}

Total count (Fig. 9d) exhibits the same behavior of $\mathrm{K}$ and $\mathrm{eTh}$, with higher values in the beginning of the line, a slight fall in the stream region, and low values in the mineralized body region.

The eU/K and eU/eTh profiles (Fig. 9e) show similar behavior among themselves, and with the uranium profile. Low values at the beginning of the profile (west) and a significant increase in the last third of the line, or, in other words, a west to east growth trend. Along these profiles, 5 peaks of eU enrichment relative to eTh and $\mathrm{K}$ were marked by arrows. The first two, A14 and A15 (Fig. 9e) have a lower amplitude, and the last three, A16, A17 and A18 (Fig. 9e) larger amplitudes. It is evident that the greatest amplitude of eU enrichment occurs where the phosphorite was mapped and marked in the profile, which illustrates that mineralized regions present low $\mathrm{K}$ and eTh values compared to eU. These points are designated for field verification.

\section{DISCUSSION AND CONCLUSIONS}

In Profile 5 , it is noteworthy the significant eU/K growth trend (Fig. 9e) from west to east. Note that the highest $\mathrm{eU} / \mathrm{K}$ and eU/eTh values coincide with the mineralized area (black line in the CT profile, Fig. 9d), thus proving the efficiency of gamma spectrometry method for mineralization mapping.

The areas marked in profiles $5 d$ (Fig. 9), do not have U-values well above the crustal average; however, they have high relative values (mean around 3-4 ppm). Some points have eU peaks with $\mathrm{K}$ and eTh depletions; important indications that there is an inverse correlation between these elements. According to these analyses, we conclude that the ratios are the best products to map phosphorite. 
It is evident from the profiles that wherever there is mineralization information (Fig. 6d, 8d, 9d) a small shift/displacement between the mineralized strip and the uranium peaks occurs. This information has various positioning bases and may contain distortion, due to the acquisition by different devices (GPS), which have varying error, or different positioning data acquisition methodology.

The careful analysis of the five gamma spectrometry terrestrial profiles shows that all known mineralizations along the profiles have high eU/eTh and eU/K values with clearly marked peaks. Hence, we conclude that the eU/eTh and eU/K profiles are the best mappers of phosphorite mineralization.

Eighteen sites were selected for investigation of radioelement anomalies. Seven of these were priority one and eleven, priority two. It is suggested that bore sampling be performed in these regions for further analysis.

\section{ACKNOWLEDGEMENTS}

Thanks are due to Itafós Mineração Ltda. for support in the field work, providing information and permission for data publication and the Superintendência de Geologia e Mineração do Governo do Estado de Goiás for the assignment of airborne geophysical data of Area V.

\section{REFERENCES}

ASHFAHANI J. 2002. Phosphate Prospecting Using Natural Gamma Ray Well Logging in the Khneifiss Mine, Syria. Available on: <http://emg.geoscienceworld.org/cgi/content/abstract/11/1-4/61>. Access on: November 16, 2009.

BECEGATO VA \& FERREIRA FJF. 2005. Gamaespectrometria, resistividade elétrica e susceptibilidade magnética de solos agrícolas no noroeste do Estado do Paraná. Brazilian Journal of Geophysics, 23(4): 371-405.

DARDENNE MA. 1978. Síntese sobre a estratigrafia do Grupo Bambuíno Brasil Central. In: Congresso Brasileiro de Geologia, 30., Recife, Brazil,
Proceedings... Sociedade Brasileira de Geologia-SBG, 2: 597-610.

DICKSON BL \& SCOTT KM. 1997. Interpretation of aerial gamma-ray surveys - adding the geochemical factors. In: Airborne Magnetic and Radiometric Surveys. ASGO Journal of Australian Geology \& Geophysics, 17: 187-200.

EXPLORANIUM. 2007. GR-320. Portable Gamma Ray Spectrometer. Users' Manual. Revision 3.5.

FERREIRA CJ, MOREIRA-NORDEMANN LM \& NORDEMANN DJR. 1992. A radioatividade natural da região de Irecê, BA. Revista Brasileira de Geociências, 22(2): 167-174.

FIANCO CB, VIDOTTIRM, PIRES ACB \& CARMELO AC. 2012. Prospecting phosphorites using airborne geophysics in northeastern Goiás State - Brazil. Brazilian Journal of Geophysics, 30(4): 459-471.

IAEA - International Atomic Energy Agency. 2003. Guideline for radioelement mapping using gamma ray spectrometry data. Vienna, Austria. $171 \mathrm{pp}$.

ITAFÓS MINERAÇÃO. 2010. Mapa litológico em SIG, escala 1:10.000. Confidential. Unpublished.

MINTY BRS. 1997. The fundamentals of airborne gamma-ray spectrometry. AGSO Journal os Australian Geology \& Geophysics, 17(2): 39-50.

MOREIRA MLO, MORETON LC, ARAÚJO VA, LACERDAJV \& COSTA HF. 2008. Geologia do Estado de Goiás e Distrito Federal. Escala 1:500.000. Goiânia: CPRM/SIC - FUNMINERAL. 141 pp.

NASCIMENTO CTC, FERREIRA FJF, ANDRADE LRM, GASPAR JC \& PIRES ACB. 2008. Radiação gama e resistividade elétrica em solo com aplicação de carbonatito e fertilizantes agrícolas no Distrito Federal. Brazilian Journal of Geophysics, 26(1): 21-29.

SOUZA JL \& FERREIRA FJF. 2005. Anomalias aerogamaespectrométricas (K, eU e eTh) da quadrícula de Araras (SP) e suas relações com processos pedogenéticos e fertilizantes fosfatados. Brazilian Journal of Geophysics, 23(3): 251-274.

WYNN J. 1996. Geophysics Applied to Phosphate Exploration in Northern Saudi Arabia. Available on:

$<$ http://volcanoes.usgs.gov/jwynn/2phos.html>. Access on: November 17, 2009.

\section{NOTES ABOUT THE AUTHORS}

Chris Busnello Fianco. M.Sc. in Applied Geosciences (Universidade de Brasília), B.Sc. in Geology (Universidade Federal do Paraná - UFPR). Four-year professional experience with airborne geophysical data acquisition and processing. Currently, works as geologist for the mining industry. Areas of interest: Applied Geophysics to mineral exploration.

Roberta Mary Vidotti. Associate Professor at the Instituto de Geociências of Universidade de Brasília. Graduated in Geology at Universidade Federal Rural do Rio de Janeiro (1987), specialized in Geology and Marine Geophysics at Universidade Federal Fluminense (1987). M.Sc. in Geophysics from Observatório Nacional (1992) 
and Ph.D. in Geophysics from the University of Leeds (1997). Has experience in Geophysics, with emphasis on gravity, magnetic and gamma ray spectrometry methods applied to regional geology, geotectonic, sedimentary basins and mineral prospecting.

Augusto César Bittencourt Pires. Ph.D. in Geophysics (Colorado School of Mines, 1975), B.Sc. in Geology (Universidade Federal do Rio de Janeiro, 1968). Former president of the SBGf (Brazilian Geophysical Society). Responsible for the Geophysics Department at ENCAL Consultores Associados; Head of the Geophysics Department at the Observatório Nacional; Head of the Applied Geophysics Center of the National Department of Mineral Production (DNPM). At the National Research Council (CNPq), held the following positions: Geosciences Supervisor, Coordinator of Exact and Earth Sciences, Superintendent of Exact and Earth Sciences and Director of Programs. Director of Programs for the Coordination of Superior Education (CAPES) and Coordinator of Policies and Plans of the Ministry of Science and Technology. Legislative Consultant for the Senate for issues referring to Mines and Energy. Specialist in the application of geophysical methods as supporting tool for geologic mapping, mineral exploration and environmental analysis. Currently works as Professor at the Instituto de Geociências of the Universidade de Brasília (UnB). 